\title{
Transfer of Risk in Emerging Eastern European Stock Markets: A Sectoral Perspective
}

\author{
Kashif Saleem ${ }^{1} \&$ Elena Fedorova ${ }^{1}$ \\ ${ }^{1}$ LUT School of Business, Lappeenranta University of Technology, Finland \\ Correspondence: Kashif Saleem, LUT School of Business, Lappeenranta University of Technology, Finland. \\ E-mail: kashif.saleem@lut.fi
}

Received: June 1, 2014

Accepted: June 20, 2014

Online Published: July 25, 2014

doi:10.5539/ibr.v7n8p134

URL: http://dx.doi.org/10.5539/ibr.v7n8p134

\begin{abstract}
This paper studies the market integration of Poland, Hungary and the Czech Republic by utilizing the multivariate GARCH analysis of Engle and Kroner (1995) for which a BEKK representation is adopted. We investigate the transmission of the US subprime crisis across Poland, Hungary and the Czech Republic in a sectoral setting. In addition, we attempt to identify whether the three emerging Eastern European countries have become more integrated after their EU accessions in 2004, in a regional setting. Our results clearly indicate the existence of direct linkages between different stock market sectors with respect to returns and volatilities. We found that the transmission of equity shocks between markets has increased after the EU accession in 2004. Notably, the intra-industry contagion in emerging Europe has increased after this accession. Our findings have significant implications for asset pricing and portfolio selection for international financial institutions and financial managers.
\end{abstract}

Keywords: market integration, GARCH, US subprime crisis, emerging Eastern European, asset pricing, portfolio selection

\section{Introduction}

This paper studies the market integration of Poland, Hungary and the Czech Republic in a sectoral setting. In particular, we look at the transmission of the US subprime crisis to Poland, Hungary and the Czech Republic, representatives of the fastest growing emerging economies of the Eastern Europe, and investigate if, and to what extent, these emerging markets have been affected by the crisis, by analyzing their stock markets and different sectors of their equity markets, particularly, Oil \& gas, Basic materials, Industrial, Consumer goods, Consumer services, Telecommunications and Financial sectors. In addition, we attempt to identify whether the three emerging Eastern European countries that we examine became more integrated after their EU accessions in 2004.

We begin from the premise that certain industries are more integrated into regional and world financial processes than other industries and are therefore more prone to contagion. If this hypothesis holds true, it should be possible to identify industries that provide risk diversification opportunities and sectors that are isolated from changes in the European financial markets. This information would allow for the application of portfolio management based on sectoral diversification to selected emerging markets, and assets of these industries could be treated as a separate class of investments.

On the subject of risk transmission mechanisms in financial market volatility there exist mixed results in the existing literature, with regards to sectoral analysis. Although the most commonly held belief regarding this topic is that the effects of country risk dominate the effects of sectoral risk (e.g., Steliaros \& Thomas, 2006; Kaltenhaeuser, 2003). However, certain researchers consider sectoral heterogeneity to be an important determinant of contagion propagation (e.g., Phylaktis \& Xia, 2009). In addition, bulk of the studies, which uses different sectors to explain intra-industry risk transfer have focused on developed stock markets (e.g., Qiao, Liew \& Wong, 2007; Hassan \& Malik, 2004; Cummins, Wei \& Xie, 2007; Prokopczuk, 2009; Brewer \& Jackson, 2002; Johnson, 2010; Tawatnuntachai \& D'Mello, 2009; Pais \& Stork, 2010). By contrast, risk transfer in emerging markets has largely evaded analysis. Some notable studies includes, Sarkar, Charkrabarti and Sen (2009) who study the volatility transmission channels among the Indian, Brazilian, Argentine and Indonesian stock markets, Lin, Penm, Wu and Chiu (2004), who study the banking sectors in China, Taiwan and Hong Kong. 
However, as per author's best knowledge, prior literature is silent on the subject of risk transmission mechanisms in sectoral setting in emerging economies of the Eastern Europe.

It is our proposition that risk and portfolio managers who are choosing asset management strategies must decide how to diversify not only their currency and liquidity risks but also the regional and sectoral allocation of their assets (Note 1). The objective of this study is defining the sectors in our selected markets, which have a unidirectional impact on local and European markets to facilitate the construction of an investment portfolio from partially segmented sectors. Our analysis is geared to understanding the volatility and shock transmission mechanism between emerging Eastern European countries and the EU.

Our sample period extends from December 1998 to December 2009 and covers Poland, Hungary and the Czech Republic. These countries joined the European Union in May 2004 but have yet to join the euro zone and continue to retain their own national currencies. These local markets were chosen for their relatively high stock market capitalizations. Moreover, these markets are relatively dynamic and have gone through major economic reforms since the early 1990s (including the privatization of state assets). These markets are more open and liquid than other markets in Eastern Europe. Furthermore, the growth of these markets has outstripped that of other markets in emerging Eastern European countries; therefore, we infer that these markets enjoy leadership roles in the region. From our research perspective, these markets are also interesting because the opening of these markets to foreign investment and world trade exposed them to external shocks from global and regional financial markets.

To study the risk transmission mechanisms in financial market volatility in sectoral setting, researchers have applied different methodologies such as, industry-decomposition method (see, e.g., Ferreira \& Gama, 2005; Black, Buckland \& Fraser, 2002), dummy-factor model introduced by Heston and Rouwenhorst (1994), two-regime Markov switching model (see, e.g., Morana \& Sawkins, 2004) and different GARCH specifications (see, e.g., Kaltenhaeuser, 2003; Qiao, Liew \& Wong, 2007; Hyytinen, 1999; Hassan and Malik, 2004 and 2007; Cotter \& Stevenson, 2006; Buguk, Hudson \& Hanson, 2003, among others). In this paper, by utilizing the multivariate GARCH analysis of Engle and Kroner (1995) for which a BEKK representation is adopted, we investigate the transmission of the US subprime crisis across Poland, Hungary and the Czech Republic in a sectoral setting. The estimations suggest the existence of direct linkages between different stock market sectors with respect to returns and volatilities. The transmission of equity shocks between markets, as per our analysis, has increased after the EU accession in 2004. Notably, the intra-industry contagion in emerging Europe has increased after this accession. Our findings have implications for asset pricing and portfolio selection for international financial institutions and financial managers.

The plan of the paper is as follows. The next section describes the bivariate GARCH models used to study the volatility spillovers among stock markets and sectoral indices and to identify the extent of US subprime contagion. Section 3 presents the data in this study. Section 4 shows the empirical results. Section 5 concludes.

\section{Model Specification}

The Generalized Autoregressive Conditional Heteroscedasticity (GARCH) process, which was developed independently by Bollerslev (1986) and Taylor (1986), is widely used for volatility modeling in financial markets. In this model, conditional variance is considered to be dependent on its previous lags. Due to the quadratic nature of the variance terms, the BEKK (Baba-Engle-Kraft-Kroner) parameterization, which was proposed by Engle and Kroner (1995), requires no restrictions on parameters to obtain positive definite values of the variance-covariance matrix. Our model complies with the hypothesis of constant correlation and allows for volatility spillover across markets (Fedorova \& Saleem, 2010).

Our empirical analysis starts with a bivariate $\operatorname{GARCH}(1,1)$ model that contains three parameters in the conditional variance equation and allows the past squared errors to influence the current conditional variance:

$$
\begin{gathered}
r_{t}=\beta r_{t-1}+\varepsilon_{t} \\
\varepsilon_{t} \mid \Omega_{t-1} \sim N\left(0, H_{t}\right)
\end{gathered}
$$

where $\mathbf{r}_{t}$ is an $n \times 1$ vector of weekly returns at time $t$ for each local stock market or its sector. The $n \times 1$ vector of random errors $\boldsymbol{\varepsilon}_{\mathrm{t}}$ represents the innovation for each market at time $\mathrm{t}$ that is available from the information set $\Omega_{t-1}$ with its corresponding $\mathrm{n} \times \mathrm{n}$ conditional variance covariance matrix $\mathrm{H}_{\mathrm{t}}$. The $\beta$ is an $\mathrm{n} \times \mathrm{n}$ matrix, with elements that represent its own and the cross-market average autoregressive terms. This multivariate structure facilitates the measurement of the effects of innovations in the mean stock returns of one market on its lagged returns and those of the lagged returns of the other market.

The BEKK parameterization constrains the estimated variances to be non-negative and maybe expressed as 
follows:

$$
H_{t}=C_{0}^{\prime} C_{0}+A_{11}^{\prime} \varepsilon_{t-1} \varepsilon_{t-1}^{\prime} A_{11}+G_{11}^{\prime} H_{t-1} G_{11}
$$

Where $\mathrm{C}_{0}$ is a $2 \times 2$ lower triangular matrix with three parameters. In Equation (3), $\mathrm{A}_{11}$ is a $2 \times 2$ square matrix of parameters that indicates the correlation of conditional variances with prior squared errors. The $A_{11}$ matrix elements capture the effects of stock market shocks on conditional variance. $G_{11}$ represents a $2 \times 2$ square matrix of parameters that captures the information regarding past effects of volatility on conditional variance. With individual elements, Equation (3) takes the following form:

$$
H_{t}=C_{0}^{\prime} C_{0}+\left[\begin{array}{ll}
a_{11} & a_{12} \\
a_{21} & a_{22}
\end{array}\right]^{\prime}\left[\begin{array}{cc}
\varepsilon_{1, t-1}^{2} & \varepsilon_{1, t-1} \varepsilon_{2, t-1} \\
\varepsilon_{1, t-1} \varepsilon_{2, t-1} & \varepsilon_{2, t-1}^{2}
\end{array}\right]\left[\begin{array}{ll}
a_{11} & a_{12} \\
a_{21} & a_{22}
\end{array}\right]+\left[\begin{array}{ll}
g_{11} & g_{12} \\
g_{21} & g_{22}
\end{array}\right]^{\prime} H_{t-1}\left[\begin{array}{ll}
g_{11} & g_{12} \\
g_{21} & g_{22}
\end{array}\right]
$$

If Equation (4) for $\mathrm{H}_{t}$ is further expanded for the bivariate $\operatorname{GARCH}(1,1)$ through matrix multiplication, the following results are obtained:

$$
\begin{gathered}
h_{11, t}=c_{11}^{2}+a_{11}^{2} \varepsilon_{1, t-1}^{2}+2 a_{11} a_{21} \varepsilon_{1, t-1} \varepsilon_{2, t-1}+a_{21}^{2} \varepsilon_{2, t-1}^{2}+g_{11}^{2} h_{11, t-1}+2 g_{11} g_{21} h_{12, t-1}+g_{21}^{2} h_{22, t-1}, \\
h_{12, t}=c_{11} c_{21}+a_{11} a_{12} \varepsilon_{1, t-1}^{2}+\left(a_{21} a_{12}+a_{11} a_{22}\right) \varepsilon_{1, t-1} \varepsilon_{2, t-1}+a_{21} a_{22} \varepsilon_{2, t-1}^{2}+g_{11} g_{12} h_{11, t-1} \\
+\left(g_{21} g_{12}+g_{11} g_{22}\right) h_{12, t-1}+g_{21} g_{22} h_{22, t-1}, \\
h_{22, t}=c_{21}^{2}+c_{22}^{2}+a_{12}^{2} \varepsilon_{1, t-1}^{2}+2 a_{12} a_{22} \varepsilon_{1, t-1} \varepsilon_{2, t-1}+a_{22}^{2} \varepsilon_{2, t-1}^{2}+g_{12}^{2} h_{11, t-1}+2 g_{12} g_{22} h_{12, t-1}+g_{22}^{2} h_{22, t-1} .
\end{gathered}
$$

The variance-covariance system can be optimized with the Berndt, Hall, Hall and Hausman (1974) algorithm (see Engle and Kroner, 1995). From Equations (5) to (7), we obtain the conditional log likelihood function L $(\theta)$ for a sample of $\mathrm{T}$ observations:

$$
\begin{gathered}
L(\theta)=\sum_{t=1}^{T} l_{t}(\theta), \\
l_{t}(\theta)=-\log 2 \pi-1 / 2 \log \left|H_{t}(\theta)\right|-1 / 2 \varepsilon_{t}^{\prime}(\theta) H_{t}^{-1}(\theta) \varepsilon_{t}(\theta),
\end{gathered}
$$

Where $\theta$ represents the vector of all of the unknown parameters. The numerical maximization of Equations (8) and (9) yields the maximum likelihood estimates with asymptotic standard errors.

We, also, test our GARCH-BEKK model for correctness, i.e., to determine whether the error terms $\varepsilon_{\mathrm{t}}$ are randomly distributed, by applying the Ljung-Box Q-statistic. This parameter is assumed to be asymptotically distributed as $\chi_{2}^{\mathrm{t}}$ with $(\mathrm{p}-\mathrm{k})$ degrees of freedom, where $\mathrm{k}$ is the number of explanatory variables in the study.

\section{Data and Descriptive Statistics}

Our sample period extends from December 1998 to December 2009 and covers Poland, Hungary and the Czech Republic. As test assets, we use market portfolios from each of the sample countries, stock market sectors and regional stock markets. As a proxy for the regional market stock returns, we use DataStream's Emerging Europe Index and European Aggregate Index. DataStream indices are constructed on a uniform basis across countries; the stock market sectoral structure for these indices is comprehensive, and the indices for selected countries exist for the entire sample period. The indices include gross dividends (i.e., they measure the total pre-tax return for investors). All of the study data are obtained from the DataStream database. We conduct our analysis from a US investor's point of view, i.e., returns are measured in US dollars. In accordance with related studies (e.g., Qiao, Liew \& Wong, 2007), we consistently use weekly total return indices based on Wednesday observations of market indices for total returns to alleviate the noise effects of daily data and day-of-the-week effects (Note 2).

Figures 1, 2 and 3 illustrate the historical development of local stock return indices for the selected sample countries. These figures reveal an insignificant non-stationary process in all of the studied markets at the beginning of the analysis period. Beginning in 2005, all of the examined stock markets demonstrate marked gains. After the 2008 financial crisis, we observe the beginnings of stock market recovery in emerging Europe during approximately the spring of 2009. From 2005 onward, the oil \& gas industry outperforms local markets in all of the examined countries. In Poland, the consumer goods, financial and basic materials sectors also outperform the market. In Hungary, high returns help the financial sector outperform the local market. In fact, the financial sector is the most attractive sector for local and international investors during the final five years of the observation period. 


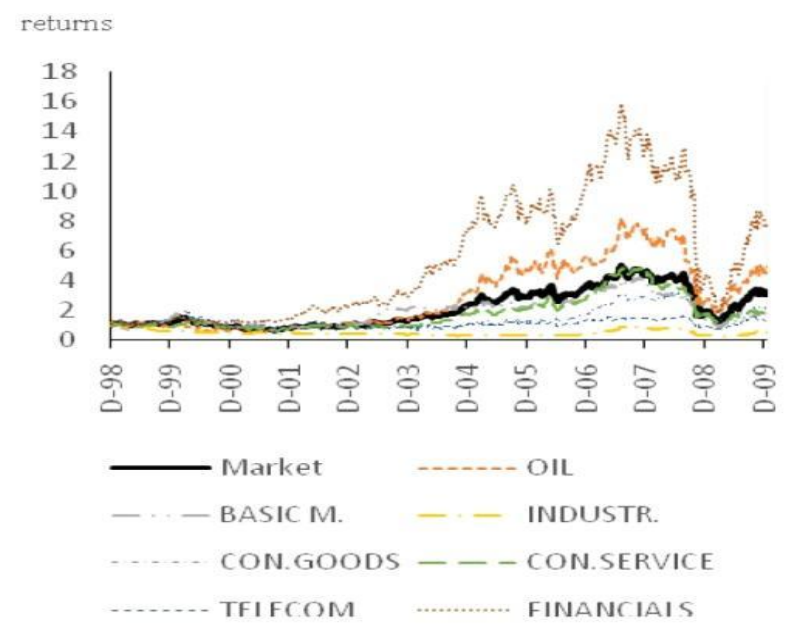

Figure 1. Polish stock return indices

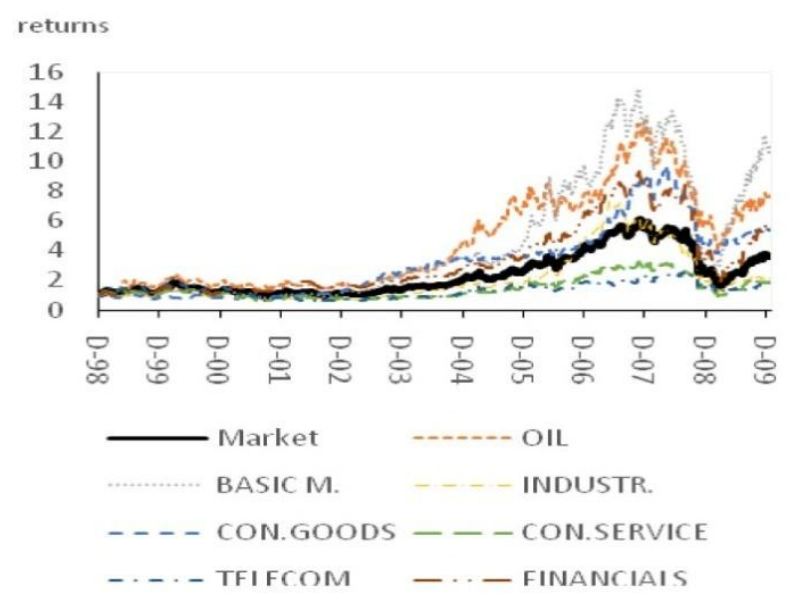

Figure 2. Hungarian stock return indices

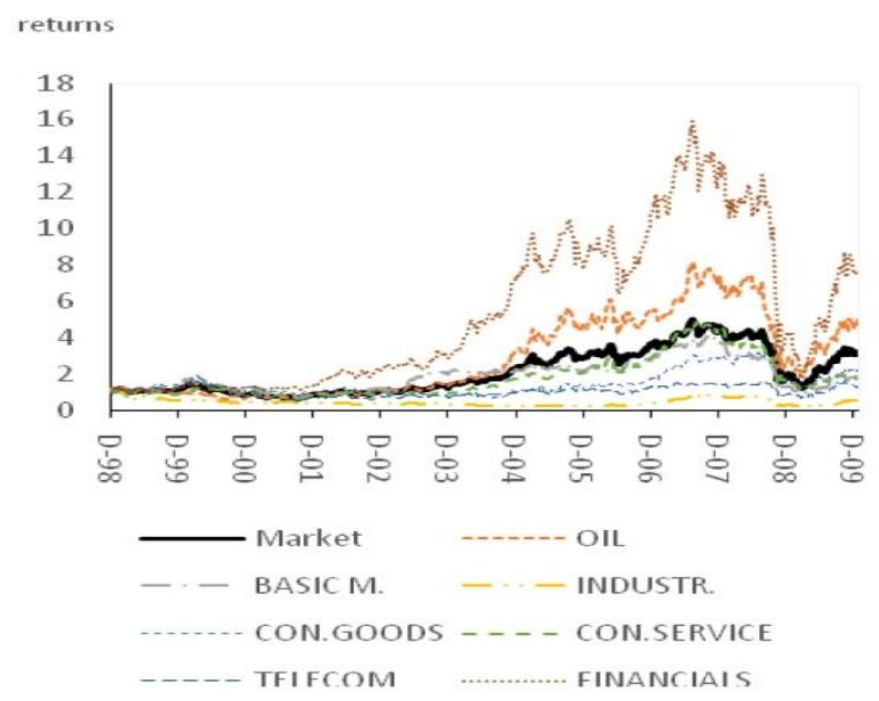

Figure 3. Czech Republican stock return indices 


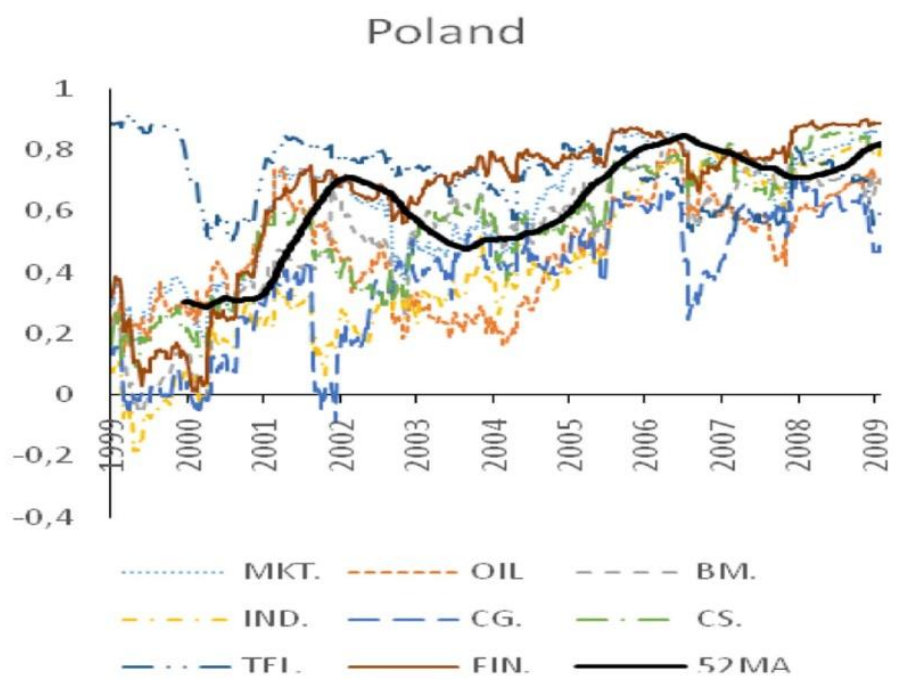

Figure 4. The 52-week rolling correlation

Interestingly, the consumer services, telecommunications and industrial sectors demonstrate below-average profitability in all of the countries that are analyzed.

Table 1 presents the descriptive statistics for Polish, Hungarian and the Czech Republic asset returns from a sectoral perspective, the values for means and standard deviations are annualized. In case of Poland, the basic materials sector provides the highest return for investors, at $21.42 \%$, whereas the highest standard deviation is observed in the telecommunications industry $(39.45 \%)$. The autocorrelation analysis reveals significant autocorrelation in the basic materials and consumer goods sectors; in the third lag, autocorrelation appears fornot only these two sectors but also the financial sector. All of the examined sectors exhibit high volatility in their asset returns. The descriptive statistics for Hungarian sectoral asset returns show the financial sector has the highest return, at $18.51 \%$ per year, and the highest volatility. All of the sectors exhibit high volatility in their asset returns. Only the industrial sector has a negative average asset return on average of $(-5.50 \%$ per year). Significant autocorrelation coefficients are observed for the consumer goods and oil \& gas sectors in the first and second lags, respectively.

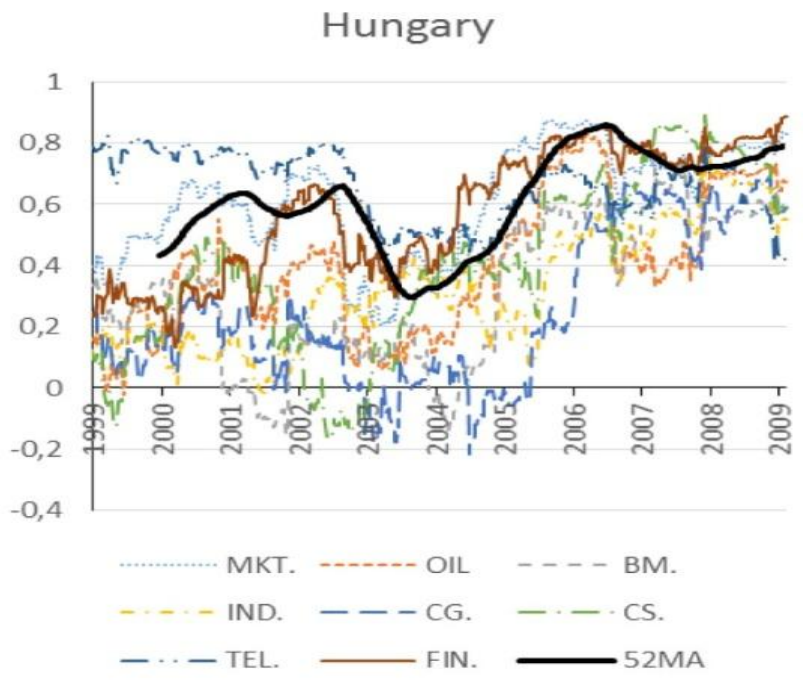

Figure 5. The 52-week rolling correlation 


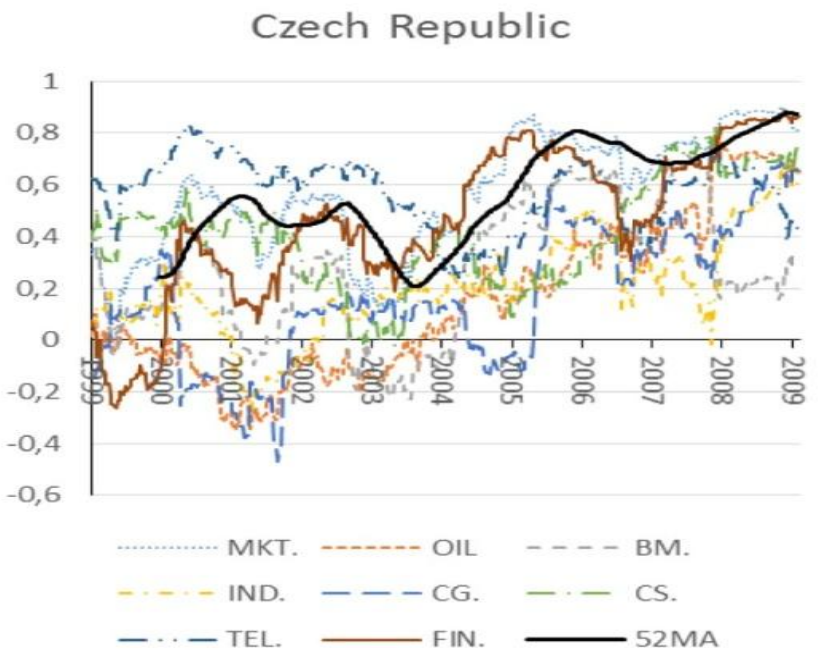

Figure 6. The 52-week rolling correlation

Finally, the highest asset returns in the Czech stock market during the sample period are obtained in the financial sector (29.59\% per year), whereas the highest volatility is in the consumer services sector (55.13\% per year). The consumer services sector is the only industry that produces a negative return $(-0.08 \%$ per year). The autocorrelation analysis demonstrates the presence of autocorrelation for the industrial sector in the first lag, for the telecommunications sector in the third lag, for the oil \& gas sector in the second and third lags, and for consumer services in the first four lags. In addition, the results of the Jargue-Bera, Augmented Dickey-Fuller and ARCH-LM tests are provided in the table. The results exhibited neither normal distribution no unit roots in time series. The homoscedasticity in residuals is rejected in all cases, suggesting the proper use of GARCH type of models.

Figures 4, 5 and 6 present the 52-week (one-year) rolling-window correlation coefficients for these analyses. The observed correlations during the sample period are volatile. Interestingly, almost all of the Polish stock market sectors, with the exception of telecommunications, are not highly correlated with the Emerging Europe Index at the beginning of the period. However, beginning from summer 2006, the Polish stock market sectors become highly correlated with other stock market sectors in emerging European countries. Our figures reveal that after the summer of 2006, sectors in emerging Europe demonstrate an increased correlation with the sectors of both the Hungarian and Czech stock markets. The moving-average trend lines for correlations between local market indices and the emerging Europe aggregate index are obtained to smooth the data fluctuations and clarify the trend. Overall, the stock market dynamics reveal an increase in correlation among the examined markets, supporting the hypothesis that during the examined period, these local markets become increasingly integrated with emerging European markets. 
Table 1. Descriptive statistics for the Polish, Hungarian and Czech sectoral asset returns

Panel A, B and C report descriptive statistics for the continuously compounded returns of the Polish, Hungarian and Czech stock market respectively. The index series are the Datastream indices. The sample period extends from November 1998 to December 2009. All of the returns are calculated in US dollars and include dividends (i.e., total return). The sample includes 580 weekly observations for each market. The means and standard deviations have been annualized. The $p$-value for the Jarque-Bera test statistic of the null hypothesis of normal distribution is provided in the table. The p-value for the Augmented Dickey-Fuller (ADF) test of null hypothesis of unit root in time series is rejected in all series. The p-value for ARCH-LM test of null hypothesis of homoscedasticity in residuals is rejected in all cases.

\begin{tabular}{|c|c|c|c|c|c|c|c|c|c|c|c|c|}
\hline \multirow[b]{2}{*}{ Asset return series } & \multirow{2}{*}{$\begin{array}{c}\text { Mean } \\
(\%)\end{array}$} & \multirow{2}{*}{$\begin{array}{c}\text { Std. dev. } \\
(\%)\end{array}$} & \multirow[t]{2}{*}{ Skewness } & \multirow{2}{*}{$\begin{array}{c}\text { Excess } \\
\text { Kurtosis }\end{array}$} & \multirow{2}{*}{$\begin{array}{r}\text { Normality } \\
\text { (p-value) }\end{array}$} & \multirow{2}{*}{$\begin{array}{c}\text { ADF } \\
\text { (p-value) }\end{array}$} & \multirow{2}{*}{$\begin{array}{c}\text { ARCH-LM } \\
\text { (p-value) }\end{array}$} & \multicolumn{4}{|c|}{ Autocorrelation } & \multirow[b]{2}{*}{$Q(27)^{b}$} \\
\hline & & & & & & & & $\rho_{1}$ & $\rho_{2}$ & $\rho_{3}$ & $\rho_{27}$ & \\
\hline \multicolumn{13}{|l|}{ Panel A: Poland } \\
\hline Oil \& gas & 17.898 & 36.256 & -0.244 & 4.283 & $<0.001$ & $<0.001$ & $<0.001$ & -0.072 & -0.007 & 0.086 & -0.068 & 0.448 \\
\hline Basic materials & 21.424 & 36.563 & -0.793 & 7.539 & $<0.001$ & $<0.001$ & $<0.001$ & $0.095^{*}$ & 0.015 & $0.174^{*}$ & -0.078 & $<0.001$ \\
\hline Industrial & 7.644 & 32.265 & -0.503 & 3.912 & $<0.001$ & $<0.001$ & $<0.001$ & 0.004 & 0.022 & 0.099 & -0.009 & 0.004 \\
\hline Consumer goods & 14.856 & 27.042 & -0.573 & 5.913 & $<0.001$ & $<0.001$ & $<0.001$ & $-0.090^{*}$ & 0.052 & $0.083^{*}$ & 0.003 & 0.030 \\
\hline Consumer services & 4.414 & 35.146 & -0.415 & 5.477 & $<0.001$ & $<0.001$ & $<0.001$ & -0.078 & 0.022 & 0.081 & -0.031 & 0.440 \\
\hline Telecommunications & 2.943 & 39.449 & 0.096 & 4.606 & $<0.001$ & $<0.001$ & $<0.001$ & -0.060 & 0.036 & 0.068 & -0.018 & 0.443 \\
\hline Financial & 13.822 & 35.491 & -1.272 & 10.855 & $<0.001$ & $<0.001$ & $<0.001$ & -0.043 & 0.047 & $0.131^{*}$ & -0.058 & $<0.001$ \\
\hline \multicolumn{13}{|l|}{ Panel B: Hungary } \\
\hline Oil \& gas & 13.863 & 42.501 & -0.675 & 8.254 & $<0.001$ & $<0.001$ & $<0.001$ & -0.006 & $-0.111^{*}$ & 0.078 & -0.069 & 0.002 \\
\hline Basic materials & 4.966 & 35.171 & -0.510 & 6.157 & $<0.001$ & $<0.001$ & $<0.001$ & 0.043 & -0.029 & 0.018 & -0.005 & 0.576 \\
\hline Industrial & -5.496 & 39.642 & -0.258 & 5.366 & $<0.001$ & $<0.001$ & $<0.001$ & -0.050 & 0.065 & 0.025 & -0.061 & 0.012 \\
\hline Consumer goods & 6.822 & 34.224 & 0.238 & 11.652 & $<0.001$ & $<0.001$ & $<0.001$ & $-0.155^{*}$ & 0.030 & 0.009 & 0.037 & 0.001 \\
\hline Consumer services & 5.060 & 35.104 & -0.520 & 10.092 & $<0.001$ & $<0.001$ & $<0.001$ & 0.059 & -0.061 & 0.038 & -0.005 & 0.535 \\
\hline Telecommunications & 1.534 & 36.823 & -0.428 & 5.035 & $<0.001$ & $<0.001$ & $<0.001$ & -0.028 & -0.050 & 0.050 & -0.010 & 0.591 \\
\hline Financial & 18.512 & 46.922 & -1.305 & 12.645 & $<0.001$ & $<0.001$ & $<0.001$ & -0.002 & 0.013 & 0.056 & -0.067 & $<0.001$ \\
\hline \multicolumn{13}{|l|}{ Panel B: Czech Republic } \\
\hline Oil \& gas & 23.681 & 32.542 & -0.409 & 8.318 & $<0.001$ & $<0.001$ & $<0.001$ & -0.048 & $0.113 *$ & $0.084^{*}$ & -0.044 & $<0.001$ \\
\hline Basic materials & 20.956 & 31.650 & -2.137 & 21.497 & $<0.001$ & $<0.001$ & $<0.001$ & 0.038 & 0.012 & 0.057 & -0.019 & 0.826 \\
\hline Industrial & 17.857 & 24.089 & 2.411 & 32.387 & $<0.001$ & $<0.001$ & $<0.001$ & $0.150^{*}$ & -0.018 & 0.055 & -0.015 & 0.037 \\
\hline Consumer goods & 14.331 & 32.133 & 0.971 & 14.576 & $<0.001$ & $<0.001$ & $<0.001$ & 0.035 & 0.020 & 0.073 & 0.015 & 0.374 \\
\hline Consumer services & -0.081 & 55.129 & -0.901 & 13.460 & $<0.001$ & $<0.001$ & $<0.001$ & $0.087^{*}$ & $0.092^{*}$ & $0.208^{*}$ & $-0.132 *$ & $<0.001$ \\
\hline Telecommunications & 9.402 & 36.727 & -0.379 & 5.029 & $<0.001$ & $<0.001$ & $<0.001$ & -0.055 & -0.015 & $0.128^{*}$ & -0.042 & 0.053 \\
\hline Financial & 29.588 & 37.700 & -0.523 & 9.327 & $<0.001$ & $<0.001$ & $<0.001$ & -0.031 & -0.015 & 0.072 & -0.014 & $<0.001$ \\
\hline
\end{tabular}

a) Autocorrelation coefficients significantly ( $5 \%$ ) different from zero are marked with an asterisk (*)

b) The $p$-value for the Ljung-Box test statistic for the null hypothesis that autocorrelation coefficients up to 27 lags (= half a year) are zero.

\section{Empirical Results}

Our empirical analysis is geared towards answering the questions that are formulated in the introduction to this paper. First, we analyze interactions both within and among the examined local markets, the Emerging Europe Index and European Union aggregates to obtain an overview of the Polish, Hungarian and Czech stock markets. Second, we analyze the risk transfers among the same sectors of stock markets in emerging Eastern Europe.

\subsection{The Inter-Dependence of Stock Market Sectors}

In first part of the analysis, we define the significance of local stock markets for the European Union with respect to market risk transfer. We study four pairs: Poland-EU, Hungary-EU, Czech Republic-EU and EE-EU. The results of these analyses are presented in Table 2. Notably, all of the local markets have the distinguishing feature that their stock market returns are dependent on their previous performance. The EU stock market performance also depends on its previous performance in all four of the aforementioned modeled pairs. Our results show in the modeled pairs a risk of shock transfer from the Czech Republic or emerging Europe to the EU. Shocks to the EU market affect the Hungarian and Czech stock markets. We document bidirectional volatility transmission almost for all modeled pairs, besides one pair with Hungary.

\subsection{Stock Market Interactions Following EU Accession In 2004}

In the second and final part of the analysis, we attempt to identify whether the three emerging Eastern European countries that we examine became more integrated after their EU accessions in 2004 (i.e., more prone to transmit investment risks from one market to another). To answer this question, we estimate three pairwise models for each stock market sector during each of two periods; the results of these estimations are reported in Table 3 . The first period, 1998-2003, includes the Asian financial crisis and its impact on European stock markets. The second period, 2004-2009, includes the potential effects of EU accession in 2004 and the global financial crisis that began in 2008 . 
Our results reveal a change in the risk of shock transfer and volatility spillovers after EU expansion. Following this expansion, the basic materials, consumer services and telecommunications sectors become more integrated within the region, whereas the consumer goods sector becomes less integrated. Notably, the overall stock market risk of shock transmission increases significantly after the EU's 2004 enlargement, whereas the average risk of volatility transfers remains the same. This change in stock markets provides evidence of increased stock market integration in Eastern European markets on the sectoral level. The interaction of stock markets with the industrial and oil \& gas sectors through shocks increases after accession, whereas the risk of volatility transfer from one regional stock market to another stock market decreases. After accession, financial markets interact more closely mainly because the examined countries share information on asset pricing and related investment risks. Interactions via volatilities in the financial stock market sector in the selected countries increase, whereas stock market interaction in this sector through shocks decrease. The overall results are clear evidence of stock market integration and increased intra-industry contagion in Eastern Europe after the EU accession of Poland, Hungary and the Czech Republic.

\subsection{Diagnostic Tests}

The diagnostic test results representing the Ljung-Box Q-statistic are reported in Panel B of Tables 2 and 3. These tests are used to assess whether the selected model is correctly specified and whether it describes the time series. We report both standardized and standardized squared residuals up to lag 24 for each modeled pair. The results demonstrate no series dependence in the squared standardized residuals, indicating the appropriateness of the GARCH-BEKK model for the study of risk transfer in emerging Eastern European stock markets. Given the large, complicated time series models of this study, we also adopt the appropriate approach of performing an augmented Dickey-Fuller (ADF) test for stock market sector cointegration. The null hypothesis of no cointegration is rejected for each modeled pair at the $1 \%$ level of significance. The results suggest the presence of interactions and cointegration between the corresponding sectors in local stock markets and the EU and linkages between sectors and their foreign counterparts. The estimated results are available upon request.

Table 2. Risk transfers between local stock markets and the European Union

The diagonal elements in matrix $\boldsymbol{B}$ represent the mean equation, whereas matrix $\boldsymbol{A}$ captures within-market and cross-market ARCH effects. The diagonal elements in matrix $\boldsymbol{G}$ measure within-market and cross-market GARCH effects. LB and $\mathrm{LB}^{2}$ present the Ljung-Box Q-statistic for standardized and standardized squared residuals. $(*)$ denotes significance at the $5 \%$ level, and $(* *)$ denotes significance at the $10 \%$ level.

\begin{tabular}{|c|c|c|c|c|}
\hline \multicolumn{5}{|c|}{ Panel A: GARCH(1,1)-BEKK estimations } \\
\hline Parameters & Poland-EU & Hungary-EU & Czech R.-EU & EE-EU \\
\hline$\beta_{1}$ & $0.004 *$ & $0.004 *$ & $0.007 *$ & $0.006^{*}$ \\
\hline$\beta_{2}$ & $0.003^{*}$ & $0.003 *$ & $0.003 *$ & $0.003^{*}$ \\
\hline $\mathrm{c}_{11}$ & $0.018^{*}$ & $0.014 *$ & $0.013^{*}$ & $0.010^{*}$ \\
\hline $\mathrm{c}_{12}$ & $0.007 *$ & 0.003 & $0.005^{*}$ & $0.006^{*}$ \\
\hline $\mathrm{c}_{22}$ & $0.004^{\mathrm{a}}$ & $0.005^{*}$ & $0.002 \mathrm{a}$ & $0.002 *$ \\
\hline$a_{11}$ & -0.056 & $0.197 *$ & $0.369 *$ & $0.344^{*}$ \\
\hline$a_{12}$ & -0.065 & -0.064 & $0.142 *$ & $0.081^{*}$ \\
\hline$a_{21}$ & 0.138 & $0.445^{*}$ & $0.164 *$ & 0.024 \\
\hline$a_{22}$ & $0.527 *$ & $0.482 *$ & $0.299 *$ & $0.306^{*}$ \\
\hline $\mathrm{g}_{11}$ & $0.637 *$ & $0.901 *$ & $0.844 *$ & $0.929 *$ \\
\hline $\mathrm{g}_{12}$ & $-0.205^{*}$ & 0.033 & $-0.073^{*}$ & $-0.024 * *$ \\
\hline $\mathrm{g}_{21}$ & $0.530^{*}$ & $-0.144 *$ & $-0.045^{* *}$ & $-0.055^{* *}$ \\
\hline $\mathrm{g}_{22}$ & $1.032 *$ & $0.850 *$ & $0.945^{*}$ & $0.920^{*}$ \\
\hline \multicolumn{5}{|c|}{ Panel B: Diagnostic tests } \\
\hline LogLik & 2451.563 & 2474.560 & 2563.643 & 2469.653 \\
\hline $\mathrm{LB}_{1}$ & 35.139 & 27.086 & 34.820 & $38.702^{*}$ \\
\hline $\mathrm{LB}_{2}$ & 31.222 & 32.684 & 31.537 & 29.683 \\
\hline $\mathrm{LB}^{2}{ }_{1}$ & 30.887 & 13.151 & 17.964 & 19.836 \\
\hline $\mathrm{LB}_{2}^{2}$ & 28.049 & 26.112 & 21.226 & 19.726 \\
\hline
\end{tabular}

a) These values are multiplied by 10,000 . 
Table 3a. Risk transfer among sectors of local stock markets

The diagonal elements in matrix $\boldsymbol{B}$ represent the mean equation, whereas matrix $\boldsymbol{A}$ captures within-market and cross-market $\mathrm{ARCH}$ effects. The diagonal elements in matrix $\boldsymbol{G}$ measure within-market and cross-market GARCH effects. LB and $\mathrm{LB}^{2}$ present the Ljung-Box Q-statistic for standardized and standardized squared residuals. $\left({ }^{*}\right)$ denotes significance at the $5 \%$ level, and $\left({ }^{* *}\right)$ denotes significance at the $10 \%$ level.

\begin{tabular}{|c|c|c|c|c|c|c|c|c|c|c|c|c|}
\hline \multicolumn{13}{|c|}{ Panel A: GARCH $(1, I)-B E K K$ estimations } \\
\hline \multirow[b]{3}{*}{ Parameters } & \multicolumn{6}{|c|}{ Oil \& Gas } & \multicolumn{6}{|c|}{ Basic Materials } \\
\hline & \multicolumn{3}{|c|}{ 1998-2003 } & \multicolumn{3}{|c|}{ 2004-2009 } & \multicolumn{3}{|c|}{ 1998-2003 } & \multicolumn{3}{|c|}{ 2004-2009 } \\
\hline & $\begin{array}{l}\text { Poland- } \\
\text { Hungary }\end{array}$ & $\begin{array}{l}\text { Poland- } \\
\text { Czech R. }\end{array}$ & $\begin{array}{l}\text { Hungary- } \\
\text { Czech R. }\end{array}$ & $\begin{array}{l}\text { Poland- } \\
\text { Hungary }\end{array}$ & $\begin{array}{l}\text { Poland- } \\
\text { Czech R. }\end{array}$ & $\begin{array}{l}\text { Hungary- } \\
\text { Czech R. }\end{array}$ & $\begin{array}{l}\text { Poland- } \\
\text { Hungary }\end{array}$ & $\begin{array}{l}\text { Poland- } \\
\text { Czech R. }\end{array}$ & $\begin{array}{l}\text { Hungary- } \\
\text { Czech R. }\end{array}$ & $\begin{array}{l}\text { Poland- } \\
\text { Hungary }\end{array}$ & $\begin{array}{l}\text { Poland- } \\
\text { Czech R. }\end{array}$ & $\begin{array}{l}\text { Hungary- } \\
\text { Czech R. }\end{array}$ \\
\hline$\beta_{1}$ & 0.003 & 0.002 & 0.003 & $0.005^{*}$ & $0.005^{*}$ & $0.007^{*}$ & $0.004 * *$ & $0.004 * *$ & 0.004 & $0.007^{*}$ & $0.006^{*}$ & 0.001 \\
\hline$\beta_{2}$ & 0.002 & $0.006^{*}$ & $0.008^{*}$ & $0.006^{*}$ & $0.005^{*}$ & $0.005^{*}$ & $0.005^{* *}$ & $0.005^{*}$ & $0.006^{*}$ & 0.001 & $0.004^{* *}$ & 0.004 \\
\hline $\mathrm{c}_{11}$ & 0.001 & $0.005^{*}$ & 0.017 & $0.036^{*}$ & $0.015^{*}$ & $0.046^{*}$ & $0.028^{*}$ & $0.033^{*}$ & 0.012 & $0.021^{*}$ & 0.001 & $0.009^{* *}$ \\
\hline$c_{12}$ & $0.008^{* *}$ & $-0.034^{*}$ & $-0.015^{*}$ & 0.005 & $0.004^{*}$ & $-9.493^{a \prime}$ & $-0.012^{*}$ & 0.002 & $0.031^{*}$ & $1.291^{\mathrm{a}}$ & $-0.022^{*}$ & $0.029^{*}$ \\
\hline $\mathrm{c}_{22}$ & $0.189^{\mathrm{a}}$ & $-0.155^{a}$ & 0.023 & $0.048^{\mathrm{a}}$ & $-0.032^{a}$ & $-0.003^{a}$ & $0.865^{\mathrm{a}}$ & -0.001 & $0.004^{\mathrm{a}}$ & $-0.001^{a}$ & $0.022^{*}$ & -0.045 \\
\hline$a_{11}$ & $0.208^{*}$ & $0.223^{*}$ & $0.235^{*}$ & 0.093 & 0.096 & $0.357^{*}$ & $0.278^{*}$ & $0.359^{*}$ & $0.311^{*}$ & $0.161^{*}$ & $0.246^{*}$ & $0.393^{*}$ \\
\hline$a_{12}$ & 0.072 & -0.005 & $-0.161^{*}$ & 0.215 & $-0.072^{*}$ & $-0.084^{*}$ & $-0.267^{*}$ & 0.095 & $-0.118^{*}$ & $0.411^{*}$ & $-0.509^{*}$ & -0.183 \\
\hline$a_{21}$ & $-0.239^{*}$ & $-0.223^{*}$ & 0.077 & $0.278^{*}$ & $0.237^{*}$ & $-0.363^{*}$ & -0.019 & -0.138 & $0.382^{*}$ & $0.360^{*}$ & $0.138^{* * *}$ & $0.169^{*}$ \\
\hline $\mathrm{a}_{22}$ & $0.165^{*}$ & $0.267^{*}$ & $-0.309^{*}$ & $0.238^{*}$ & $0.500^{*}$ & $0.520^{*}$ & $0.438^{*}$ & $0.147^{*}$ & $0.354^{*}$ & -0.032 & $0.851^{*}$ & $0.325^{*}$ \\
\hline $\mathrm{g}_{\| 1}$ & $0.555^{*}$ & $0.935^{*}$ & $0.886^{*}$ & 0.252 & $0.928^{*}$ & -0.050 & 0.530 & 0.335 & $0.843^{*}$ & $0.631^{*}$ & $1.014^{*}$ & $0.939^{*}$ \\
\hline $\mathrm{g}_{12}$ & $-0.587^{*}$ & 0.039 & $0.391 *$ & $0.358^{* * *}$ & -0.015 & 0.030 & 0.414 & -0.166 & -0.044 & $-0.266^{*}$ & $0.368^{*}$ & $0.367^{*}$ \\
\hline $\mathrm{g}_{21}$ & $0.664^{*}$ & $0.356^{* *}$ & $-0.386^{*}$ & 0.246 & $-0.053^{* *}$ & $0.789^{*}$ & 0.190 & 0.156 & 0.108 & $0.396^{*}$ & $-0.266^{*}$ & $-0.309^{*}$ \\
\hline $\mathrm{g}_{22}$ & $0.955^{*}$ & 0.189 & $0.573^{*}$ & $0.717^{*}$ & $0.896^{*}$ & $0.879^{*}$ & $0.730^{*}$ & $0.997^{*}$ & 0.201 & $0.986^{*}$ & 0.032 & $0.596^{*}$ \\
\hline \multicolumn{13}{|c|}{ Panel B: Diagnostic tests } \\
\hline LogLik & 881.372 & 934.546 & 957.975 & 1049.496 & 1159.848 & 1084.808 & 927.932 & 1027.692 & 972.792 & 1106.459 & 1033.180 & 1083.786 \\
\hline $\mathrm{LB}_{1}$ & 21.098 & 21.384 & 18.894 & $42.328^{*}$ & $39.106^{*}$ & $39.094^{*}$ & 24.316 & 25.091 & $16.624^{* *}$ & $59.375^{*}$ & $53.170^{*}$ & 24.361 \\
\hline $\mathrm{LB}_{2}$ & 17.864 & $36.967^{* *}$ & 35.221 & 33.012 & 21.235 & 23.280 & 18.854 & 33.017 & 37.414 & 19.860 & 16.220 & 13.355 \\
\hline $\mathrm{LB}_{1}^{2}$ & 18.453 & 20.369 & 26.575 & 22.819 & 19.594 & 33.690 & 10.429 & 11.687 & 28.669 & 28.225 & 33.577 & 23.906 \\
\hline $\mathrm{LB}_{2}^{2}$ & 18.019 & $40.966^{*}$ & 29.189 & 27.016 & 25.898 & 25.944 & 21.903 & 19.058 & 28.334 & $36.757^{* *}$ & 6.702 & 2.397 \\
\hline
\end{tabular}

Table 3b. Risk transfer among sectors of local stock markets (continue)

The diagonal elements in matrix $\boldsymbol{B}$ represent the mean equation, whereas matrix $\boldsymbol{A}$ captures within-market and cross-market ARCH effects. The diagonal elements in matrix $\boldsymbol{G}$ measure within-market and cross-market GARCH effects. LB and $\mathrm{LB}^{2}$ present the Ljung-Box Q-statistic for standardized and standardized squared residuals. $\left({ }^{*}\right)$ denotes significance at the $5 \%$ level, and $(* *)$ denotes significance at the $10 \%$ level.

\begin{tabular}{|c|c|c|c|c|c|c|c|c|c|c|c|c|}
\hline \multicolumn{13}{|c|}{ Panel A: GARCH(1,I)-BEKK estimations } \\
\hline \multirow[b]{3}{*}{ Parameters } & \multicolumn{6}{|c|}{ Industrial } & \multicolumn{6}{|c|}{ Consumer Goods } \\
\hline & \multicolumn{3}{|c|}{ 1998-2003 } & \multicolumn{3}{|c|}{ 2004-2009 } & \multicolumn{3}{|c|}{ 1998-2003 } & \multicolumn{3}{|c|}{ 2004-2009 } \\
\hline & $\begin{array}{l}\text { Poland- } \\
\text { Hungary }\end{array}$ & $\begin{array}{l}\text { Poland- } \\
\text { Czech R. }\end{array}$ & $\begin{array}{l}\text { Hungary- } \\
\text { Czech R. }\end{array}$ & $\begin{array}{l}\text { Poland- } \\
\text { Hungary }\end{array}$ & $\begin{array}{l}\text { Poland- } \\
\text { Czech R. }\end{array}$ & $\begin{array}{l}\text { Hungary- } \\
\text { Czech R. }\end{array}$ & $\begin{array}{l}\text { Poland- } \\
\text { Hungary }\end{array}$ & $\begin{array}{l}\text { Poland- } \\
\text { Czech R. }\end{array}$ & $\begin{array}{l}\text { Hungary- } \\
\text { Czech R. }\end{array}$ & $\begin{array}{l}\text { Poland- } \\
\text { Hungary }\end{array}$ & $\begin{array}{l}\text { Poland- } \\
\text { Czech R. }\end{array}$ & $\begin{array}{l}\text { Hungary- } \\
\text { Czech R. }\end{array}$ \\
\hline$\beta_{1}$ & 0.002 & $3.642^{\mathrm{a}}$ & -0.003 & $0.005^{*}$ & $0.006^{*}$ & 0.004 & $0.005^{*}$ & $0.006^{*}$ & $0.005^{*}$ & $0.003^{* *}$ & $0.003^{*}$ & $0.006^{*}$ \\
\hline$\beta_{2}$ & -0.001 & 0.003 & 0.001 & 0.003 & $0.004^{*}$ & $0.005^{*}$ & -0.001 & $0.009^{*}$ & $0.007^{*}$ & $0.004 * *$ & 0.001 & -0.001 \\
\hline $\mathrm{c}_{11}$ & 0.013 & 0.002 & $0.006^{\mathrm{a}}$ & 0.002 & $0.008^{*}$ & $0.023^{*}$ & $0.021^{*}$ & $-0.010^{*}$ & $0.034^{*}$ & $0.018^{*}$ & $0.013^{*}$ & $0.008^{*}$ \\
\hline $\mathrm{c}_{12}$ & $0.025^{*}$ & -0.009 & $0.001^{\mathrm{a}}$ & $-0.020^{*}$ & -0.001 & -0.001 & $0.024^{*}$ & $0.025^{*}$ & 0.008 & $0.010^{*}$ & 0.006 & $0.023^{*}$ \\
\hline $\mathrm{c}_{22}$ & -0.038 & $0.038^{*}$ & $0.001^{\mathrm{a}}$ & $0.026^{*}$ & $-0.001^{a}$ & $-0.001^{a}$ & $0.019^{*}$ & $-0.002^{\mathrm{a}}$ & 0.002 & $0.018^{a}$ & $0.001^{\mathrm{a}}$ & $0.019^{*}$ \\
\hline$a_{\| 1}$ & $0.210^{*}$ & $0.206^{* *}$ & $0.123^{*}$ & $0.315^{*}$ & $0.347^{*}$ & $0.274^{*}$ & $0.557^{*}$ & $0.442^{*}$ & $-0.351^{*}$ & $0.460^{*}$ & $0.413^{*}$ & $0.279^{*}$ \\
\hline$a_{12}$ & $0.320^{*}$ & -0.106 & $0.192^{*}$ & $0.315^{*}$ & $0.081^{*}$ & $0.130^{*}$ & $0.168^{*}$ & 0.101 & $0.778^{*}$ & $0.115^{* *}$ & $0.231^{*}$ & -0.081 \\
\hline$a_{21}$ & $-0.137^{*}$ & 0.114 & 0.043 & $0.082^{* *}$ & -0.056 & -0.255 & 0.071 & 0.059 & -0.032 & 0.006 & -0.031 & -0.045 \\
\hline$a_{22}$ & $0.229^{*}$ & $0.194^{*}$ & 0.023 & $0.251^{*}$ & $0.184^{*}$ & $0.258^{*}$ & $0.253^{*}$ & $0.350^{*}$ & $0.431^{*}$ & $0.199^{*}$ & $0.215^{*}$ & $0.344^{*}$ \\
\hline $\mathrm{g}_{11}$ & $0.588^{*}$ & $0.833^{*}$ & $0.874^{*}$ & $0.971^{*}$ & $0.916^{*}$ & $0.725^{*}$ & $0.609^{*}$ & $0.577^{*}$ & -0.166 & $0.738^{*}$ & $0.742^{*}$ & $0.961^{*}$ \\
\hline $\mathrm{g}_{12}$ & $-0.793^{*}$ & -0.029 & $-0.295^{*}$ & 0.141 & $-0.028^{*}$ & $-0.156^{*}$ & $-0.340^{*}$ & $-0.513^{*}$ & $0.626^{*}$ & $-0.163^{* *}$ & $-0.418^{*}$ & 0.048 \\
\hline $\mathrm{g}_{21}$ & $0.448^{*}$ & $-0.511^{*}$ & $0.563^{*}$ & $-0.079^{* *}$ & 0.045 & $0.740^{*}$ & -0.367 & $0.490^{*}$ & -0.129 & 0.007 & $0.194^{*}$ & -0.055 \\
\hline $\mathrm{g}_{22}$ & $0.662^{*}$ & -0.118 & $0.905^{*}$ & $0.615^{*}$ & $0.980^{*}$ & $0.927^{*}$ & 0.331 & $0.664^{*}$ & $-0.426^{*}$ & $0.979^{*}$ & $0.987^{*}$ & $0.642^{*}$ \\
\hline \multicolumn{13}{|c|}{ Panel B: Diagnostic tests } \\
\hline LogLik & 901.922 & 961.852 & 909.795 & 1044.893 & 1284.868 & 1210.967 & 1030.843 & 966.897 & 979.428 & 1131.844 & 1181.431 & 1050.121 \\
\hline $\mathrm{LB}_{1}$ & $37.706^{* *}$ & $37.354^{* *}$ & $50.185^{*}$ & $41.526^{*}$ & $39.890^{*}$ & $47.444^{*}$ & 30.225 & 28.692 & 22.348 & 29.692 & 27.880 & 22.590 \\
\hline $\mathrm{LB}_{2}$ & $49.274^{*}$ & 27.010 & 30.507 & $42.913^{*}$ & 28.842 & 28.011 & 21.385 & 19.693 & 30.453 & 23.868 & $35.521^{*}$ & 34.401 \\
\hline $\mathrm{LB}^{2}{ }_{1}$ & 25.266 & 20.811 & 13.229 & 35.560 & $35.759^{* *}$ & $42.959^{*}$ & 25.093 & 16.259 & 15.658 & 27.209 & 21.327 & 6.081 \\
\hline $\mathrm{LB}_{2}^{2}$ & 15.778 & 2.494 & 5.190 & 32.528 & 14.774 & 20.221 & 15.708 & 6.822 & 23.729 & 7.156 & 21.984 & 19.710 \\
\hline
\end{tabular}


Table 3c. Risk transfer among sectors of local stock markets (continue)

The diagonal elements in matrix $\boldsymbol{B}$ represent the mean equation, whereas matrix $\boldsymbol{A}$ captures within-market and cross-market $\mathrm{ARCH}$ effects. The diagonal elements in matrix $\boldsymbol{G}$ measure within-market and cross-market GARCH effects. LB and $\mathrm{LB}^{2}$ present the Ljung-Box Q-statistic for standardized and standardized squared residuals. $\left({ }^{*}\right)$ denotes significance at the $5 \%$ level, and $\left({ }^{* *}\right)$ denotes significance at the $10 \%$ level.

\begin{tabular}{|c|c|c|c|c|c|c|c|c|c|c|c|c|}
\hline \multicolumn{13}{|c|}{ Panel A: GARCH(I,I)-BEKK estimations } \\
\hline \multirow[b]{3}{*}{ Parameters } & \multicolumn{6}{|c|}{ Consumer Services } & \multicolumn{6}{|c|}{ Telecommunications } \\
\hline & \multicolumn{3}{|c|}{ 1998-2003 } & \multicolumn{3}{|c|}{ 2004-2009 } & \multicolumn{3}{|c|}{ 1998-2003 } & \multicolumn{3}{|c|}{ 2004-2009 } \\
\hline & $\begin{array}{l}\text { Poland- } \\
\text { Hungary }\end{array}$ & $\begin{array}{l}\text { Poland- } \\
\text { Czech R. }\end{array}$ & $\begin{array}{l}\text { Hungary- } \\
\text { Czech R. }\end{array}$ & $\begin{array}{l}\text { Poland- } \\
\text { Hungary }\end{array}$ & $\begin{array}{l}\text { Poland- } \\
\text { Czech R. }\end{array}$ & $\begin{array}{l}\text { Hungary- } \\
\text { Czech R. }\end{array}$ & $\begin{array}{l}\text { Poland- } \\
\text { Hungary }\end{array}$ & $\begin{array}{l}\text { Poland- } \\
\text { Czech R. }\end{array}$ & $\begin{array}{l}\text { Hungary- } \\
\text { Czech R. }\end{array}$ & $\begin{array}{l}\text { Poland- } \\
\text { Hungary }\end{array}$ & $\begin{array}{l}\text { Poland- } \\
\text { Czech R. }\end{array}$ & $\begin{array}{l}\text { Hungary- } \\
\text { Czech R. }\end{array}$ \\
\hline$\beta_{1}$ & 0.001 & $14.566^{a}$ & 0.001 & $0.006^{*}$ & $0.005^{*}$ & $0.006^{*}$ & $1.030^{\mathrm{a}}$ & $-4.456^{\mathrm{a}}$ & 0.001 & 0.002 & 0.003 & 0.003 \\
\hline$\beta_{2}$ & $29.891^{\text {* }}$ & 0.005 & 0.002 & $0.006^{*}$ & $0.005^{*}$ & $0.007^{*}$ & $8.751^{\mathrm{a}}$ & $-3.573^{\mathrm{a}}$ & 0.001 & 0.001 & $0.005^{*}$ & $0.005^{*}$ \\
\hline$c_{11}$ & 0.010 & $0.040^{*}$ & 0.009 & $0.015^{*}$ & $0.022^{*}$ & $0.034^{*}$ & $0.020^{*}$ & $0.020^{*}$ & 0.007 & $0.028^{*}$ & $0.030^{*}$ & $0.014^{*}$ \\
\hline$c_{12}$ & $-0.022^{*}$ & -0.004 & $0.058^{*}$ & $-0.016^{*}$ & $0.006^{*}$ & 0.003 & -0.006 & 0.006 & -0.011 & 0.002 & -0.003 & -0.003 \\
\hline $\mathrm{c}_{22}$ & 0.117 & $0.012^{\mathrm{a}}$ & -0.005 & -0.018 & $-0.001^{\mathrm{a}}$ & $-0.001^{\text {a }}$ & 0.005 & $0.001^{a}$ & 0.054 & $-0.001^{a}$ & 0.004 & 0.021 \\
\hline$a_{11}$ & $-0.236^{*}$ & -0.126 & 0.125 & $0.400^{*}$ & $-0.191^{*}$ & $0.331^{*}$ & 0.099 & $0.365^{*}$ & $0.308^{*}$ & -0.071 & $0.207^{*}$ & $0.307^{*}$ \\
\hline$a_{12}$ & $0.124^{*}$ & $0.150^{*}$ & $0.685^{*}$ & $0.446^{*}$ & $0.114 *$ & $0.121^{*}$ & $-0.234^{*}$ & 0.076 & -0.098 & $-0.212^{* *}$ & 0.058 & $0.192^{*}$ \\
\hline$a_{21}$ & -0.014 & $-0.129^{*}$ & $0.228^{*}$ & -0.084 & $0.101^{*}$ & $0.271^{*}$ & $-0.235^{*}$ & $-0.218^{*}$ & 0.052 & $0.514^{*}$ & -0.011 & $0.232^{*}$ \\
\hline$a_{22}$ & $0.458^{*}$ & $0.245^{*}$ & $0.158^{* *}$ & 0.097 & $0.363^{*}$ & $0.427^{*}$ & $0.284^{*}$ & $-0.213^{*}$ & $0.311^{*}$ & $0.457^{*}$ & $0.409^{*}$ & $0.216^{*}$ \\
\hline $\mathrm{g}_{11}$ & $0.949^{*}$ & $0.382^{* *}$ & $0.630^{*}$ & -0.216 & $0.828^{*}$ & $0.227^{*}$ & $0.858^{*}$ & $0.620^{*}$ & $1.097^{*}$ & $0.715^{*}$ & 0.070 & $0.800^{*}$ \\
\hline $\mathrm{g}_{12}$ & $0.206^{*}$ & 0.053 & -0.172 & $0.460^{*}$ & -0.021 & -0.097 & 0.048 & $-0.510^{*}$ & $0.906^{*}$ & $0.293^{*}$ & $0.631^{*}$ & $-0.146^{*}$ \\
\hline $\mathrm{g}_{21}$ & 0.006 & $0.208^{*}$ & $0.369^{*}$ & $1.008^{*}$ & $0.049 * *$ & $0.108^{*}$ & $0.169^{*}$ & $0.465^{*}$ & $-0.590^{*}$ & -0.142 & $0.844^{*}$ & $0.157^{*}$ \\
\hline $\mathrm{g}_{22}$ & $0.681^{*}$ & $0.941^{*}$ & 0.018 & $0.416^{*}$ & $0.927^{*}$ & $0.941^{*}$ & $0.916^{*}$ & $1.019^{*}$ & $0.274^{*}$ & $0.730^{*}$ & 0.229 & $0.996^{*}$ \\
\hline \multicolumn{13}{|c|}{ Panel B: Diagnostic tests } \\
\hline LogLik & 880.036 & 806.156 & 805.670 & 1139.302 & 1058.420 & 1063.305 & 826.067 & 760.678 & 841.805 & 1110.642 & 1147.498 & 1152.680 \\
\hline $\mathrm{LB}_{1}$ & 23.079 & 27.008 & 26.615 & 21.618 & 21.062 & 31.860 & 24.910 & 25.682 & 34.377 & 18.857 & 16.241 & 30.004 \\
\hline $\mathrm{LB}_{2}$ & 28.899 & 14.592 & 18.674 & 30.396 & 35.035 & 29.523 & 32.423 & 30.700 & 22.300 & $35.328^{* *}$ & 26.909 & 30.049 \\
\hline $\mathrm{LB}^{2}{ }_{1}$ & 19.820 & 22.095 & 22.322 & $46.104^{*}$ & $38.379^{*}$ & 20.136 & 23.148 & 18.822 & 26.834 & 29.563 & 25.129 & 25.209 \\
\hline $\mathrm{LB}_{2}{ }_{2}$ & 22.154 & 12.825 & 26.162 & 19.762 & 7.877 & 6.232 & 17.539 & 25.632 & 19.585 & 34.381 & 32.567 & 34.934 \\
\hline
\end{tabular}

Table 3d. Risk transfer among sectors of local stock markets (continue)

The diagonal elements in matrix $\boldsymbol{B}$ represent the mean equation, whereas matrix $\boldsymbol{A}$ captures within-market and cross-market ARCH effects. The diagonal elements in matrix $\boldsymbol{G}$ measure within-market and cross-market GARCH effects. LB and $\mathrm{LB}^{2}$ present the Ljung-Box Q-statistic for standardized and standardized squared residuals. $(*)$ denotes significance at the $5 \%$ level, and $(* *)$ denotes significance at the $10 \%$ level.

\begin{tabular}{|c|c|c|c|c|c|c|}
\hline \multicolumn{7}{|c|}{ Panel A: GARCH(1,1)-BEKK estimations } \\
\hline \multirow[b]{3}{*}{ Parameters } & \multicolumn{6}{|c|}{ Financial } \\
\hline & \multicolumn{3}{|c|}{ 1998-2003 } & \multicolumn{3}{|c|}{ 2004-2009 } \\
\hline & Poland-Hungary & Poland-Czech R. & Hungary-Czech R. & Poland-Hungary & Poland-Czech R. & Hungary-Czech R. \\
\hline$\beta_{1}$ & 0.002 & 0.002 & 0.004 & $0.007 *$ & $0.007^{*}$ & $0.008^{*}$ \\
\hline$\beta_{2}$ & 0.004 & $0.006^{*}$ & $0.008^{*}$ & $0.008^{*}$ & $0.008^{*}$ & $0.009 *$ \\
\hline $\mathrm{c}_{11}$ & $0.021 *$ & $0.026^{*}$ & 0.004 & $0.012 *$ & $0.018 *$ & $0.012 *$ \\
\hline$c_{12}$ & 0.009 & -0.002 & $0.012 *$ & $-0.661^{\mathrm{a}}$ & $-0.015^{*}$ & $-0.026^{*}$ \\
\hline $\mathrm{c}_{22}$ & 0.010 & $0.008^{*}$ & -0.014 & -0.001 & $-0.003^{\mathrm{a}}$ & -0.003 \\
\hline$a_{11}$ & $0.178 * *$ & 0.127 & -0.002 & $0.191 * *$ & 0.143 & $0.280 *$ \\
\hline$a_{12}$ & $0.276^{*}$ & -0.142 & $-0.273^{*}$ & $0.470 *$ & $0.402 *$ & 0.005 \\
\hline$a_{21}$ & $-0.250 *$ & $0.343^{*}$ & $-0.258^{*}$ & 0.036 & 0.013 & 0.104 \\
\hline$a_{22}$ & 0.033 & $0.225^{*}$ & $0.220^{*}$ & 0.099 & $0.170^{*}$ & $0.685^{*}$ \\
\hline $\mathrm{g}_{11}$ & $0.668^{*}$ & $0.545^{* *}$ & $0.924^{*}$ & $0.762^{*}$ & $0.530^{*}$ & $0.302 *$ \\
\hline $\mathrm{g}_{12}$ & -0.259 & 0.030 & -0.054 & $-0.244 *$ & -0.002 & $0.284^{*}$ \\
\hline $\mathrm{g}_{21}$ & $0.136^{*}$ & 0.048 & $0.135^{*}$ & $0.170 *$ & $0.456^{*}$ & $0.842 *$ \\
\hline $\mathrm{g}_{22}$ & $0.992 *$ & $0.944 *$ & $0.918^{*}$ & $1.042 *$ & $0.830 *$ & $0.366^{*}$ \\
\hline \multicolumn{7}{|c|}{ Panel B: Diagnostic tests } \\
\hline LogLik & 988.965 & 1007.858 & 965.181 & 1055.252 & 1098.418 & 995.204 \\
\hline $\mathrm{LB}_{1}$ & $48.458 *$ & $45.690^{*}$ & 23.562 & $42.727^{*}$ & $42.479 *$ & 25.472 \\
\hline $\mathrm{LB}_{2}$ & 23.727 & 15.662 & 16.409 & 18.959 & 29.920 & 32.078 \\
\hline $\mathrm{LB}^{2}{ }_{1}$ & 25.269 & 19.917 & 28.816 & 15.138 & 14.166 & 22.169 \\
\hline $\mathrm{LB}_{2}{ }_{2}$ & 26.250 & 24.734 & 27.779 & 14.728 & 26.958 & $42.948 *$ \\
\hline
\end{tabular}

a) These values are multiplied by 10,000 . 


\section{Summary and Conclusions}

In this paper, we analyzed financial risk and mechanisms of transfer in emerging European stock markets. We studied the intra-industry relationship for investment risk transfers in emerging Eastern European stock markets (specifically, Poland, Hungary and the Czech Republic) and their linkage with the European Union stock market using a GARCH-BEKK model. Our weekly data span the period from December 1998 to December 2009. Particularly, we examined the interdependence of sectors in emerging stock markets of Eastern Europe. Finally, we discussed investment risk changes in emerging Eastern European countries over the course of the past decade.

While investigating the transmissions of risks between EU and local markets of Eastern Europe the results indicated a risk of shock transfer from the Czech Republic and emerging Europe to the EU. The EU's stock market affects the Hungarian and Czech stock markets in terms of shock. The bidirectional volatility transmission is reported for almost all markets, besides Hungary.

Our empirical findings reveals that the scope of shock transmissions between similar sectors in stock markets has increased after EU accession, indicating that accession led to increased integration in European stock markets; thus, these markets are increasingly susceptible to contagion. These findings are consistent with the results of earlier research with respect to both the increased integration of European countries (e.g., Fedorova \& Vaihekoski, 2009) and transfers among different stock market sectors (e.g., Phylaktis \& Xia, 2009).

To extend this research, it might be productive to study inter-industry dependence in the markets of other emerging European countries and the significance of these emerging European markets for various European and overseas stock markets. The analysis that is provided in the current study would also benefit from an investigation of the interdependence among emerging European stock markets and the largest members of the EU economy. Regime-switching models could also be tested to obtain a more accurate description of stock market interactions during times of crisis.

\section{References}

Berndt, E. K., Hall, B. H., \& Hall, R. E. (1974). Estimation and inference in nonlinear structural models. Annals of Economic and Social Measurement, 3(4), 103-116.

Black, A., Buckland, R., \& Fraser, P. (2002). Efficient portfolio diversification: Changing UK stock market sector and sub-sector volatilities, 1968-2000. Managerial Finance, 28(8), 26-43. http://dx.doi.org/10.1108/03074350210767997

Bollerslev, T. (1986). General Autoregressive Conditional Heteroscedasticity. Journal of Econometrics, 31, 309-328. http://dx.doi.org/10.1016/0304-4076(86)90063-1

Brewer, E., \& Jackson, W. (2002). Inter-industry contagion and the competitive effects of financial distress announcements: Evidence from commercial banks and life insurance companies. Federal Reserve Bank of Chicago, unpublished working paper WP-02-23. Retrivied from http://ideas.repec.org/p/fip/fedhwp/wp-02-23.html

Buguk, C., Hudson, D., \& Hanson, T. (2003). Price volatility spillover in agricultural markets: An examination of US catfish markets. Journal of Agricultural and Resource Economics, 28(1), 86-99.

Cotter, J., \& Stevenson, S. (2006). Multivariate modeling of daily REIT volatility. The Journal of Real Estate Finance and Economics, 32, 305-325. http://dx.doi.org/10.1007/s11146-006-6804-9

Cummins, J., Wei, R., \& Xie, X. (2007). Financial sector integration and information spillovers: Effects of operational risk events on U.S. banks and insurers. Unpublished working paper. Retrieved from http://ssrn.com/abstract $=1071824$

Engle, R., \& Kroner, K. (1995). Multivariate Simultaneous Generalized ARCH. Econometric Theory, 11, 122-150. http://dx.doi.org/10.1017/S0266466600009063

Fedorova, E., \& Saleem, K. (2010). Volatility Spillovers between Stock and Currency Markets: Evidence from Emerging Eastern Europe. Czech Journal of Economics and Finance, 60(6), 519-533.

Fedorova, E., \& Vaihekoski, M. (2009). Global and local sources of risk in Eastern European emerging stock markets. Czech Journal of Economics and Finance, 59(1), 2-19.

Ferreira, M., \& Gama, P. (2005). Have world, country and industry risks changed over time? An investigation of the volatility of developed stock markets. The Journal of Financial and Quantitative Analysis, 40(1), 195-222. http://dx.doi.org/10.1017/S0022109000001794 
Hassan, S., \& Malik, F. (2004). Modeling volatility in sector index returns with GARCH models using an iterated algorithm. Journal of Economics and Finance, 28(2), 211-225. http://dx.doi.org/10.1007/BF02761612

Hassan, S., \& Malik, F. (2007). Multivariate GARCH modeling of sector volatility transmission. The Quarterly Review of Economics and Finance, 47, 470-480. http://dx.doi.org/10.1016/j.qref.2006.05.006

Heston, S., \& Rouwenhorst, K. (1994). Does Industrial Structure Explain the Benefits of International Diversification? Journal of Financial Economics, $36, \quad 3-27$. http://dx.doi.org/10.1016/0304-405X(94)90028-0

Hyytinen, A. (1999). Stock return volatility on Scandinavian stock markets and the banking industry. Bank of Finland Discussion Papers No.19/99. Retrieved from http://ssrn.com/abstract=1021220

Johnson, W. (2010). International financial freedoms, banks, contagion and the market crisis of 2007-2009. Unpublished working paper. Retrieved from http://ssrn.com/abstract=1459517

Kaltenhaeuser, B. (2003). Country and sector-specific spillover effects in the euro area, the United States and Japan. European Central Bank Working Paper No. 286. Retrieved from http://www.ecb.int

Lin, S., Penm, J., Wu, S, \& Chiu, W. (2004). A Factor-GARCH approach to conditional risk and return in banking stocks: Comparison of industry effects in Taiwan, Hong Kong and Mainland China. Unpublished working paper. Retrieved from http://ssrn.com/abstract=485882

Morana, C., \& Sawkins, J. (2004). Stock market volatility of regulated industries: An empirical assessment. Portuguese Economic Journal, 3, 189-204. http://dx.doi.org/10.1007/s10258-004-0030-2

Pais, A., \& Stork, P. (2011). Contagion risk in the Australian banking and property sectors. Journal of Banking and Finance, 35(3), 681-697. http://dx.doi.org/10.1016/j.jbankfin.2010.05.012

Phylaktis, K., \& Xia, L. (2009). Equity market comovement and contagion: A sectoral perspective. Financial Management, 38(2), 381-409. http://dx.doi.org/10.1111/j.1755-053X.2009.01040.x

Prokopczuk, M. (2009). Intra-industry contagion effects of earnings surprises in the banking sector. SSRN Banking and Insurance Journal. Retrieved from http://ssrn.com/abstract=1546468

Qiao, Z., Liew, V., \& Wong, W. (2007). Does the US IT stock market dominate other IT stock markets: Evidence from multivariate GARCH model? Economics Bulletin, 6(27), 1-7. http://www.accessecon.com/pubs/EB/2007/Volume6/EB-06F30029A.pdf

Sarkar, A., Chakrabarti, G., \& Sen, C. (2009). Indian stock volatility in recent years: Transmission from global and regional contagion and traditional domestic sectors. Journal of Asset Management, 10, 63-71. http://dx.doi.org/10.1057/jam.2008.29

Steliaros, M., \& Thomas, D. (2006). The cross-sectional variability of stock-price returns: Country and sector effects revisited. Journal of Asset Management, 7, 273-290. http://dx.doi.org/10.1057/palgrave.jam.2240218

Tawatnuntachai, O., \& D'Mello, R. (2009). Intra-industry reactions of stock split announcements. The Journal of Financial Research, 25(1), 39-57. http://dx.doi.org/10.1111/1475-6803.00003

Taylor, S. (1986). Modelling Financial Time Series. Chichester, England: Wiley.

\section{Notes}

Note 1. Ferreira and Gama (2005) and Black, Buckland and Fraser (2002) argue that the industry-decomposition method is superior to the geographical decomposition method with respect to portfolio management

Note 2. Day-of-the-week effect is tested in the study, where no effect was found on Wednesday. The results of the tests are not reported here but are available upon request from the authors.

\section{Copyrights}

Copyright for this article is retained by the author(s), with first publication rights granted to the journal.

This is an open-access article distributed under the terms and conditions of the Creative Commons Attribution license (http://creativecommons.org/licenses/by/3.0/). 